\title{
Essential oil of Cinnamodendron dinisii Schwanke for the control of Sitophilus zeamais Motschulsky (Coleoptera: Curculionidae)
}

\author{
VEDOVATTO, F.'; VALÉRIO JÚNIOR, C.1; ASTOLFI, V.'; MIELNICZKI, P.A.A.'; ROMAN, S.S.'; PAROUL, N.'; \\ CANSIAN, R.L."** \\ -Universidade Regional Integrada do Alto Uruguai e das Missões, Campus Erechim, Av. Sete de Setembro, \\ 1621- CEP 99700-000, Erechim - RS, Brasil. *Autor para correspondência: cansian@uricer.edu.br
}

\begin{abstract}
The use of natural compounds is a less aggressive alternative for the control of insects in stored grains, in relation to synthetic chemical agents. Plants with insecticidal properties can be used as a source of these compounds to the direct application in pest control. In this work, the essential oil of Cinnamodendron dinisii was chemically characterized and tested regarding its insecticidal and repellent effect on the control of Sitophilus zeamais in stored grains. The essential oil was obtained by hydrodistillation and analyzed by gas chromatography-mass spectrometry (GC-MS). The insecticidal potential was evaluated through the maintenance of the insects during 24 hours in contact with several doses of the oil, in the absence of feed substrate. The Bioassays of repellency were conducted with lethal doses $\left(\mathrm{LD}_{5}, \mathrm{LD}_{25}, \mathrm{LD}_{50}\right.$ and $\mathrm{LD}_{95}$ ) obtained from insecticidal bioassay. In order to compare the treatments, the preference index (PI) was used. The essential oil of $C$. dinisii had insecticidal activity against $S$. zeamais, causing a linear and crescent mortality with LD of $0.04,0.17,0.34$ and $0.63 \mu \mathrm{L} / \mathrm{cm}^{2}$, respectively. The repellency ranged from $55.4 \%$ to $85.2 \%$, using the $L D$ values previously mentioned. The $\mathrm{DL}_{5}$ was neutral regarding repellence $(\mathrm{PI}$ index $-0,09)$, but from $\mathrm{DL}_{25}$ on, the $\mathrm{PI}$ index was between -0.1 and -1.0 , indicating repellence activity.
\end{abstract}

Keywords: essential oil, insecticidal, repellence, Sitophilus zeamais.

RESUMO: Óleo essencial de Cinnamodendron dinisii Schwanke para controle de Sitophilus zeamais Motschulsky (Coleoptera: Curculionidae). O uso de compostos naturais é uma alternativa menos agressiva para o controle de insetos em grãos armazenados em relação aos agentes químicos sintéticos. Plantas com propriedades inseticidas podem ser usadas como fonte destes compostos para a aplicação direta no controle de pragas. No presente trabalho, o óleo essencial de Cinnamodendron dinisii foi caracterizado quimicamente e testado em relação ao seu efeito repelente inseticida no controle de Sitophilus zeamais em grãos armazenados. O óleo essencial foi obtido por hidrodestilação e analisado por cromatografia gasosa-espectrometria de massa (GC-MS). O potencial inseticida foi avaliado pela manutenção dos insetos durante 24 horas em contato com várias doses de óleo, na ausência de substrato alimentar. Os bioensaios de repelência foram realizados com as doses letais $\left(\mathrm{DL}_{5}, \mathrm{DL}_{25}, \mathrm{DL}_{50}\right.$ e $\mathrm{DL}_{95}$ ) obtidas do bioensaio inseticida. Para comparar os tratamentos foi utilizado o índice de preferência $(\mathrm{PI})$. O óleo essencial de $C$. dinisii apresentou atividade inseticida sobre $S$. zeamais, causando mortalidade linear e crescente com DL de 0,04, 0,17, 0,34 e 0,63 $\mathrm{LL} / \mathrm{cm}^{2}$, respectivamente. A repelência variou entre $55,4 \%$ até $85,2 \%$, utilizando os valores de $D L$ acima mencionados. $\mathrm{ADL}_{5}$ mostrou-se neutra em relação à repelência (índice $\mathrm{PI}-0,09$ ), mas a partir de $\mathrm{DL}_{25}$ o índice PI foi entre $-0,1$ e -1,0, indicando atividade de repelência.

Palavras-chave: óleo essencial, inseticida, repelência, Sitophilus zeamais.

\section{INTRODUCTION}

Insects' attacks are related to significant economic losses in stored grains (Tibola et al., 2009). Sitophilus zeamais Motschulsky (Coleoptera: Curculionidae), popularly known as maize weevil, is one of the main pests of stored grains in Brazil, which present elevated biotic potential, cross-infestation and that housing inside the whole grains (Pimentel et al., 2009). Besides, it has great reproductive 
potential and colonizes many hosts as wheat, corn, rice, barley, triticale and oats (Lorini, 2008).

Insecticidal plants are an alternative to the control of insects' in stored grains, and can be used to the synthesis of new products or even in the direct control of pests. Secondary metabolites or bioactive compounds present in some botany extracts are toxic to insects by affect its development during the grain colonization (Michaelraj \& Sharma, 2006; Azmir et al., 2013). The bioactive compounds can be extracted from leaves, stems, flowers and fruits (Azmir et al., 2013). In these sense, natural insecticides based on essential oil represent an option for the protection of stored products (Isman, 2000).

The efficiency of several vegetal species against $S$. zeamais and other grains-related pests has been demonstrated. Essential oils of Elaeis guineensis (palm oil) (Abulude et al., 2007), Piper aduncum and Piper hispidinervum (Piperaceae) (Estrela et al., 2006), Vermonia amigdalya (Compositae) (Asawalam \& Hassanali, 2006), Eucalyptus spp (Myrtaceae) (Negahban \& Moharramipour, 2007; Mossi et al., 2011), Ocotea odorifera (Lauraceae) (Mossi et al., 2014), were investigated to the control of $S$. zeamais. In all cases the insect was sensitive, at least in some degree, showing that $S$. zeamais can be controlled with bioactive compounds.

The use of natural products instead synthetic chemical pesticides is an alternative that can reduce the agriculture impact on the environment. The choice of native species as source of oil and/ or extracts employed in pest control could be a strategy to their sustainable use by local communities, and consequently contribute to their conservation. The Cinnamodendron dinisii Schwanke, popularly known as pimenteira, is a native tree of Atlantic Forest, encountered from southeast (Minas Gerais state) until the southern (Rio Grande do Sul state) of Brazil. Is a robust tree, with trunk clear and leaves with spice flavor. C. dinisii is abundant in Rio Grande do Sul state, inclusive in the neighborhood of agricultural regions (Souza \& Lorenzi, 2012). The evaluation of the insecticide and repellent potential of essential oil of this species is relevant in order to support the development of molecules or products formulated for this purpose. In These sense, the objective of this work was characterize chemically the essential oil of C. dinisii and evaluate its insecticidal and repellent effect upon the control of $S$. zeamais in stored grains.

\section{MATERIALS AND METHODS Biological samples \\ Leaves of Cinnamodendron dinisii Schwanke (Canellaceae) was collected in Erechim, RS, Brazil $\left(27^{\circ} 38^{\prime} 58.88^{\prime \prime} \mathrm{S}, 52^{\circ} 16^{\prime} 12.52^{\prime \prime} \mathrm{W}\right)$ in summer, always}

in the morning. Exsiccates were identified and maintained at Padre Balduino Rambo Herbarium of URI - Erechim (HPBR n. 11.807). Following the collection, the vegetal samples were dried at $30-40^{\circ} \mathrm{C}$ until constant weight.

\section{Extraction and characterization of essential oil \\ The essential oil of $C$. dinisii was extracted} from aerial parts of the samples by hydrodistillation in Clevenger (Farmacopéia Brasileira, 1988). The oil was kept in glass recipient at $-20^{\circ} \mathrm{C}$ until the subsequent assays. The chromatographic analyses of the essential oil was performed using a Shimadzu QP 5050A series gas chromatograph coupled to mass spectrometer (GC-MS), using a DB-5 fused silica capillary column $(30 \mathrm{~m} \times 0.25$ $\mathrm{mm}$ internal diameter $\times 0.25 \mu \mathrm{m}$ film thickness). Samples of $50.000 \mathrm{ppm}$ dilluted in hexane were subjected to chromatography with flow of $1 \mathrm{~mL}$ min$1,1.6 \mathrm{Kv}$ detector and solvent cutting at $3.5 \mathrm{~min}$. The temperature program used for the analysis was: initial temperature at $50^{\circ} \mathrm{C}$, held for $3 \mathrm{~min}$, and ramped at $5^{\circ} \mathrm{C} \mathrm{min}{ }^{-1}$ to $130^{\circ} \mathrm{C}$, then $20^{\circ} \mathrm{C} \mathrm{min}-1$ to $250^{\circ} \mathrm{C}$. Helium was used as a carrier gas at a flow rate of $1 \mathrm{~mL} \mathrm{~min}-1$. The detector temperature was set to $250^{\circ} \mathrm{C}$, and the injector temperature $240^{\circ} \mathrm{C}$ with injection port (split 1:20). The oil compounds were identified by comparison of mass spectra of each peak with those of authentic samples in a mass spectrum library (The Wiley Registry of Mass Spectral Data, 7th ed.), tables of Kovats indices (Adams, 2007) and references from literature.

\section{Creation, development and maintenance of $S$. zeamais}

Sitophilus zeamais Motschulsky (Coleoptera: Curculionidae) were obtained in silos of corn storage. The insects were kept at $25^{\circ} \mathrm{C}\left( \pm 2^{\circ} \mathrm{C}\right)$ and $75 \%$ relative humidity in 1 liter glass bottle containing corn grains (Mossi et al., 2011). The corn used in the experiments was sterilized at $-80^{\circ} \mathrm{C}$ ( 24 hours). For the assays, 20 adult insects were incubated in glass bottle with sterile corn during 15 days, until eggs outbreak. At this time, adult insects were discarded, using in the experiments, insects with 2 weeks of postemergence (Mossi et al., 2014).

\section{Evaluation of insecticidal activity}

Essential oil of C. dinisii was applied in filter paper packed into circular plates, without feed substrate, on which were put glass beads to simulate grain presence. The tested doses were 115 , $100,85,70,55,30,15$ e $5 \mu \mathrm{L} /$ plate, corresponding respectively to $0.75,0.65,0.52,0.45,0.36,0.19$, 0.10 e $0.03\left(\mu \mathrm{L} \mathrm{cm}^{-2}\right)$. In each test were used 50

Rev. Bras. PI. Med., Campinas, v.17, n.4, supl. III, p.1055-1060, 2015. 
adult insect, not sexed. The plates were maintained in dark room, $20^{\circ} \mathrm{C}( \pm 2 \mathrm{C})$, and insect mortality was determined after 24 hour (Mossi et al., 2014). The experiments were repeated three independent times with 2 plates for each treatment. Were considered dead the insects who showed no reaction to the touch with metallic tweezers (Pinto Junior et al., 2010). The mortality curve was obtained plotting the oil dose applied against the number of death insects, which generate an equation used to calculate the lethal doses $\left(\mathrm{LD}_{5}, \mathrm{LD}_{25}, \mathrm{LD}_{50}\right.$ and $\left.\mathrm{LD}_{95}\right)$. The statistical analyzes was performed by ANOVA plus Tukey test, with $p<0.05$ considered significant.

\section{Evaluation of repellent activity}

The Bioassays of repellency were conducted in an arena with a central plate $(14 \mathrm{~cm}$ diameter $2 \mathrm{~cm}$ height, $153.9 \mathrm{~cm}^{2}$, without feed substrate) interconnected to four plates disposed diagonally, with $20 \mathrm{~g}$ of corn each (Mossi et al., 2014), being that in two opposite plates were tested the lethal doses $\left(\mathrm{LD}_{5}, \mathrm{LD}_{25}, \mathrm{LD}_{50}\right.$ e $\left.\mathrm{LD}_{95}\right)$ and the two other plates were used as control (without oil). Adult insects were starved of feed for 3 hours before the experiment (Tavares \& Vendramim, 2005) and then put in the central plate (20 insects). After 24 hours, the number of insects that migrated to each peripherally plate was determined. The repellency assay was repeated three independent times with 2 plates for each treatment and the average percentage were used to calculate the preference index $(\mathrm{PI})$ (Procópio et al., 2003):

$$
P I=\frac{\% \text { of insects in test plates }-\% \text { of insects in control plates }}{\% \text { of insects in test plates }+\% \text { of insects in control plates }}
$$

Where PI values means:

-1.00 to -0.10 , repellent activity

-0.10 to +0.10 , neutral repellence

+0.10 to +1.0 , attract activity

\section{RESULTS AND DISCUSSION Extraction and characterization of $C$. dinisii essential oil}

The yield of $C$. dinisii essential oil was $0.62 \%$ after 2 hour of extraction, which was higher than yield of $0.17 \%$ obtained by Torres et al. (2010) with Capsicodendron dinisii (synonymy of $C$. dinisii).

Based on chromatography analyses were identified 23 major compounds in the essential oil of C. dinisii, with predominance of bicyclogermacrene (26.19\%), spathulenol $(24.21 \%)$, terpinyl acetate $(16.34 \%)$ and alpha terpineol (7.34\%) (Table 1).

Chemical compounds were grouped into 4 classes: monoterpenes, oxygenated monoterpenes, sesquiterpenes and oxygenated sesquiterpenes. A fifty class formed by acetates (ester derived from monoterpene alcohols) was separated from oxygenated monoterpenes due its high concentration. As observed in Table 1, the majority fraction is composed by sesquiterpenes (37.92\%) and oxygenated sesquiterpenes $(27.28 \%)$ which corresponds to $65.20 \%$ of all identified compounds.

No data were found in the literature about insecticidal activity of the major compounds present in the essential oil analyzed in these work. However, it was described that $\alpha$-terpinolene (Pietro et al., 2010), a-terpineol (Lima et al., 2009) and germacrene D and germacrene B (Bamontri \& Mazoochi, 2009) have insecticidal properties and are present in the essential oil analyzed in this work, but in lower percentages, except the alpha terpineol which showed percentage of $7.34 \%$. Thus, the insecticidal action of $C$. dinisii oil (described below) is probably related to synergistic effect of several compounds instead action of major compounds acting isolated.

\section{Insecticidal activity}

The mortality of $S$. zeamais after 24 hours- exposure to different dosage of $C$. dinisii oil is shown in (Figure 1). This result demonstrate an insecticidal action with a linear correlation between oil dosage and insect mortality $\left(R^{2} 0.9503\right)$. Based on the equation generated by mortality curve, $\mathrm{LD}_{50}$ was established in $51.69 \mu \mathrm{L} /$ plate $\left(0.34 \mu \mathrm{L} / \mathrm{cm}^{2}\right)$. The $\mathrm{LD}_{95}, \mathrm{LD}_{25}, \mathrm{LD}_{5}$, were calculated in $97.04 \mu \mathrm{L} /$ plate $\left(0.63 \mu \mathrm{L} / \mathrm{cm}^{2}\right), 26.50 \mu \mathrm{L} /$ plate $\left(0.17 \mu \mathrm{L} / \mathrm{cm}^{2}\right)$ and 6.35 $\mu \mathrm{L} /$ plate $\left(0.04 \mu \mathrm{L} / \mathrm{cm}^{2}\right)$, respectively. These values of LD were subsequently used in the repellence assay. Comparison between mortality produced by several concentrations of the essential oil is present in (Table 2). The doses of 100 and 115 $\mu \mathrm{L} /$ plate resulted in $97.33 \%$ and $100 \%$ of lethality, respectively, not differing statistically each other, but differing in relation to the lower doses. In other words, $100 \mu \mathrm{L} /$ plate $\left(0.65 \mu \mathrm{L} / \mathrm{cm}^{2}\right)$ is a dose sufficiently efficient to the control of $S$. zeamais in experimental conditions and could be used in mini silos and repellence assays.

The $\mathrm{LD}_{50}$ obtained in this work $\left(0.34 \mu \mathrm{L} / \mathrm{cm}^{2}\right)$ was similar to the values described with essential oil of other vegetal species that have good insecticidal activity upon S. zeamais, as Schinus molle that 
TABLE 1. Compounds and their respective percentage in essential oil $f$. dinisii.

\begin{tabular}{|c|c|c|}
\hline Compound & Kovats Index & Peak area (\%) \\
\hline Terpinolene & 1064 & 1.03 \\
\hline Camphor & 1139 & 0.73 \\
\hline Alpha Terpineol & 1148 & 7.34 \\
\hline Linalyl Acetate & 1261 & 0.46 \\
\hline Isopulegyl Acetate & 1275 & 2.72 \\
\hline Gama Elemene & 1340 & 0.35 \\
\hline Alpha Cubebene & 1345 & 0.16 \\
\hline 6-Metil-5-hepten-6-one & 1348 & 0.95 \\
\hline Terpinyl Acetate & 1352 & 16.34 \\
\hline Alpha Copaene & 1377 & 1.69 \\
\hline Geranyl Acetate & 1382 & 1.25 \\
\hline Beta Elemene & 1393 & 0.48 \\
\hline Iso Caryofyllene & 1438 & 2.72 \\
\hline Alpha Humulene & 1467 & 0.83 \\
\hline Beta caryophyllene & 1470 & 0.34 \\
\hline Germacrene D & 1487 & 1.14 \\
\hline Bicyclogermacrene & 1517 & 26.19 \\
\hline Germacrene B & 1562 & 0.49 \\
\hline Isoledene & 1569 & 3.53 \\
\hline Caryophyllene Oxide & 1573 & 0.75 \\
\hline Spathulenol & 1619 & 24.21 \\
\hline Viridiflorol & 1754 & 0.27 \\
\hline Drimenol & 1764 & 2.05 \\
\hline \multicolumn{3}{|l|}{ Groups } \\
\hline Monoterpenes & & 1.03 \\
\hline Oxygenated Monoterpenes & & 9.02 \\
\hline Monoterpene Esters & & 20.77 \\
\hline Sesquiterpenes & & 37.92 \\
\hline Oxygenated Sesquiterpenes & & 27.28 \\
\hline Total & & $96.02 \%$ \\
\hline
\end{tabular}

Kovats index (Adams, 2007).

showed $\mathrm{LD}_{50}$ of $0.25 \mu \mathrm{L} / \mathrm{cm}^{2}$ (Fernandes \& Favero, 2014); Piper aduncum and Piper hispidinervum, with $\mathrm{LD}_{50}$ of $0.51 \mu \mathrm{L} / \mathrm{cm}^{2}$ and $2.85 \mu \mathrm{L} / \mathrm{cm}^{2}$, respectively (Estrela et al., 2006); Eucalyptus saligna with LD $_{50}$ of $0.36 \mu \mathrm{L} / \mathrm{cm}^{2}$ and Cupressus semprevirens $\mathrm{LD}_{50}$ of $0.84 \mu \mathrm{L} / \mathrm{cm}^{2}$ (Tapondjou et al., 2005). These data indicate that several plants have potential to the control of S. zeamais, and then the choice of the best specie should take into account factors related to sustainable management, as regional availability and ecological importance of the species.

\section{Repellence activity}

The repellency assays of $C$. dinisii essential oil upon $S$. zeamais, were performed using $\mathrm{LD}_{5}$, $\mathrm{LD}_{25}, \mathrm{LD}_{50}$ and $\mathrm{LD}_{95}$ aforementioned, the data are summarized in (Table 3).

Doses between $0.17 \mu \mathrm{L} / \mathrm{cm}^{2}$ and $0.63 \mu \mathrm{L} /$ $\mathrm{cm}^{2}$, show no statistical differences each other, presenting a good repellent effect of $C$. dinisii essential oil (around 72.9 and $85.2 \%$ ). Similar data were obtained by Ootani et al. (2011) for Cymbopogon nardus and Corymbia citriodora. Oils of these two species had repellence between $86.6 \%$ and $98.8 \%$ upon $S$. zeamais, in concentrations range from 0.66 until $1.32 \mu \mathrm{L} / \mathrm{cm}^{2}$.

In the (Table 4), are shown the preference indexes $(\mathrm{PI})$ of $\mathrm{S}$. zeamais in relation to the essential oil dosage. The lower PI was obtained with $0.63 \mu \mathrm{L} /$ $\mathrm{cm}^{2}\left(\mathrm{LD}_{95}\right)$, pointing to the better repellent effect upon the insects. The concentration of $0.04 \mu \mathrm{L} / \mathrm{cm}^{2}\left(\mathrm{LD}_{5}\right)$ was neutral in relation to the repellency and the 
FIGURE 1. Mortality curve of S. zeamais treated with C. dinisii essential oil.

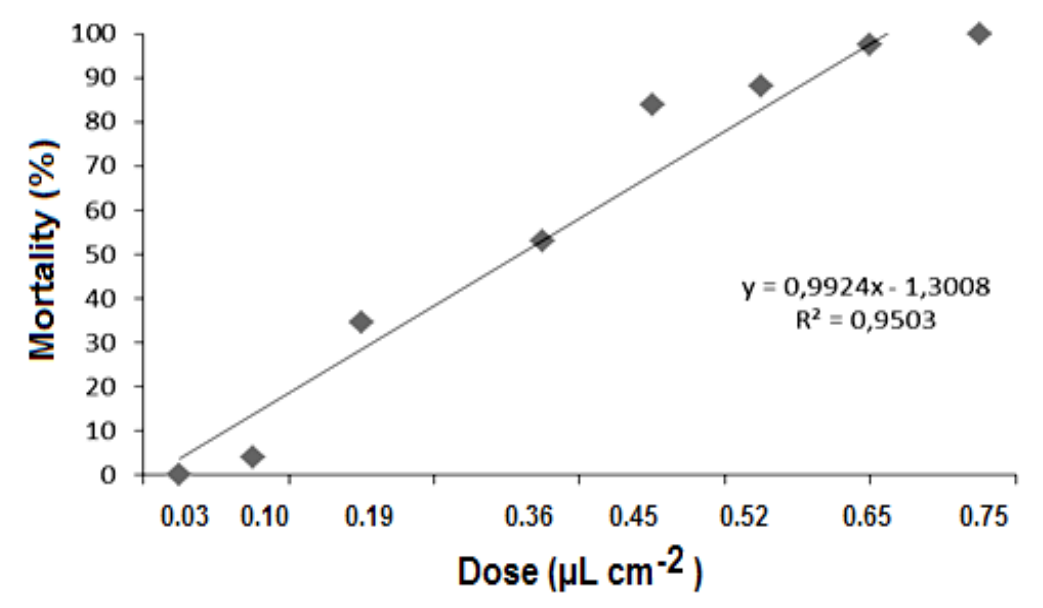

TABLE 2. Insectidal action of C. dinisii essential oil upon S. zeamais.

\begin{tabular}{ll}
\hline Doses & Mortality (\%)* \\
\hline $0.03 \mu \mathrm{L} / \mathrm{cm}^{2}(5 \mu \mathrm{L} /$ plate $)$ & $0.0^{\ddagger} \pm 0.0$ \\
$0.10 \mu \mathrm{L} / \mathrm{cm}^{2}(15 \mu \mathrm{L} /$ plate $)$ & $4.0^{\circ} \pm 2.0$ \\
$0.19 \mu \mathrm{L} / \mathrm{cm}^{2}(30 \mu \mathrm{L} /$ plate $)$ & $34.7^{\mathrm{d}} \pm 5.0$ \\
$0.36 \mu \mathrm{L} / \mathrm{cm}^{2}(55 \mu \mathrm{L} /$ plate $)$ & $54.0^{\circ} \pm 4.0$ \\
$0.45 \mu \mathrm{L} / \mathrm{cm}^{2}(70 \mu \mathrm{L} /$ plate $)$ & $84.0^{\mathrm{b}} \pm 4.0$ \\
$0.52 \mu \mathrm{L} / \mathrm{cm}^{2}(80 \mu \mathrm{L} /$ plate $)$ & $88.0^{\mathrm{b}} \pm 2.0$ \\
$0.65 \mu \mathrm{L} / \mathrm{cm}^{2}(100 \mu \mathrm{L} /$ plate $)$ & $97.3^{\mathrm{a}} \pm 1.1$ \\
$0.75 \mu \mathrm{L} / \mathrm{cm}^{2}(115 \mu \mathrm{L} /$ plate $)$ & $100.0^{\mathrm{a}} \pm 0.0$ \\
\hline
\end{tabular}

* The data are presented as media \pm SD (standard derivation). Different letters indicate statistical differences at $p<0.05$ (as analyzed by ANOVA plus Tukey test).

TABLE 3. Repellent activity of $C$. dinisii essential oil upon S. zeamais.

\begin{tabular}{ll}
\hline Dose & Repellency (\%) \\
\hline $0.04 \mu \mathrm{L} / \mathrm{cm}^{2}\left(\mathrm{LD}_{5}\right)$ & $55.4^{\mathrm{b}} \pm 9.3$ \\
$0.17 \mu \mathrm{L} / \mathrm{cm}^{2}\left(\mathrm{LD}_{25}\right)$ & $72.9^{\mathrm{a}, \mathrm{b}} \pm 4.6$ \\
$0.34 \mu \mathrm{L} / \mathrm{cm}^{2}\left(\mathrm{LD}_{50}\right)$ & $78.3^{\mathrm{a}} \pm 9.8$ \\
$0.63 \mu \mathrm{L} / \mathrm{cm}^{2}\left(\mathrm{LD}_{95}\right)$ & $85.2^{\mathrm{a}} \pm 6.0$ \\
\hline
\end{tabular}

* The data are presented as media \pm SD (standard derivation). Different letters indicate statistical differences at $p<0.05$ (as analyzed by ANOVA plus Tukey test).

doses of $0.17 \mu \mathrm{L} / \mathrm{cm}^{2}\left(\mathrm{LD}_{25}\right)$ and $0.34 \mu \mathrm{L} / \mathrm{cm}^{2}\left(\mathrm{LD}_{50}\right)$ was intermediate effect of repellency.

The data shown a linear correlation between oil dosage and PI, i.e., as high was the dose of $C$. dinisii lower will be the PI of the insects, increasing the repellency.

There are no studies in the literature about C. dinisii effect upon S. zeamais, but the results obtained in the present work are similar to those
TABLE 4. Preference index (PI) of $S$. zeamais after treatment with different doses of $C$. dinisii essential oil.

\begin{tabular}{ll}
\hline Dose & Preference index $(\mathrm{PI})^{*}$ \\
\hline $0.04 \mu \mathrm{L} / \mathrm{cm}^{2}\left(\mathrm{LD}_{5}\right)$ & -0.09 \\
$0.17 \mu \mathrm{L} / \mathrm{cm}^{2}\left(\mathrm{LD}_{25}\right)$ & -0.37 \\
$0.34 \mu \mathrm{L} / \mathrm{cm}^{2}\left(\mathrm{LD}_{50}\right)$ & -0.48 \\
$0.63 \mu \mathrm{L} / \mathrm{cm}^{2}\left(\mathrm{LD}_{95}\right)$ & -0.62 \\
\hline Linear correlation between & $\mathrm{y}=-0.8203 \mathrm{x}-0.1501\left(\mathrm{R}^{2}\right.$ \\
oil dosage and $\mathrm{PI}$ & $0,8626)$ \\
\hline
\end{tabular}

* PI values means: -1.00 to -0.10 , repellent activity; -0.10 to +0.10 , neutral repellence; +0.10 to +1.0 , attract activity.

encountered with several species described as repellents against the refereed insect. Procópio et al. (2003) investigating the PI of six vegetal species upon $S$. zeamais, verified the better repellence with Eucalyptus citriodora (PI -0.81). Mossi et al. (2011), using $\mathrm{LD}_{50}$ between 0.08 and $0.79 \mu \mathrm{L} / \mathrm{cm}^{2}$, observed PI values from -0.50 until -0.69 for several Eucalyptus spp. Reichert et al. (2013) demonstrated that Baccharis dracunculifolia had PI ranging from -0.67 and -0.93 para $S$. zeamais, when tested in the concentration of 0.06 to $0.65 \mu \mathrm{L} / \mathrm{cm}^{2}$.

Considering the possibility that insects can acquire resistance against actives principles from different origins, the study of essential oils can be an alternative to the seek new bioproducts used directly on insect control or even, new molecular models to the production of pesticides less aggressive to the environment. The essential oils and their byproducts have been considered a good choice to the insect's control, since they have quickly degradation, causing minor effects upon beneficial species of insects (Tripathi et al., 2009). Besides, the application of native species as source of oils and/ or extracts employed in favor of the agriculture 
could be a strategy to their sustainable use by local communities, and consequently contribute to their conservation. In this study, the application of $C$. dinisii in the combat of $S$. zeamais showed promising results, which and could be explored to the adequate management of this tree in fragments of Atlantic Forest.

\section{ACKNOWLEDGEMENTS}

The authors thanks the CNPq, FAPERGS and SIT-RS by the financial support and fellowships concession.

\section{REFERENCES}

ABULUDE, F.O. et al. Effect of palm oil in protecting stored grains from Sitophilus zeamais and Callosobruchus maculatus. Journal of Entomology, v. 4, n. 5, p. 393396, 2007.

ADAMS, R.P. Identification of essential oil components by gas cromatography/mass spectroscopy. $4^{\circ} \mathrm{Ed}$., Allured Publ. Corp, Carol Stream, 2007.

ASAWALAM, E.F.; HASSANALI. A. Constituents of the essential oil of Vernonia amygdalina as maize weevil protectants. Tropical and subtropical agroecosystems, v. 6, p. 95-102, 2006.

AZMIR, J. et al. Techniques for extraction of bioactive compounds from plant materials: A review. Journal of Food Engineering, v. 117, p. 426-436, 2013.

BAMONTRI, A.; MAZOOCHI, A. Determination of bioactive and fragrance molecules from leaves and fruits of Ferula assa-foetida L. growing in central Iran by nano scale injection. Digest Journal of Nanomaterials and Biostructures, v. 4, n. 2, p. 323-328, 2009.

MICHAELRAJ, S.; SHARMA, R.K. Fumigant toxicity of neem formulations against Sitophilus oryzae and Rhyzopertha dominica. Journal of Agricultural Technology, v. 2, n. 1, p. 1-16, 2006.

ESTRELA, J.LV. et al. Toxicidade de óleos essenciais de Piper aduncum e Piper hispidinervum em Sitophilus zeamais. Pesquisa Agropecuária Brasileira, v. 41, p. 217-222, 2006

FARMACOPÉIA BRASILEIRA. 4. ed. São Paulo: Atheneu, 1988. p.V.4.2-4.2.5.

FERNANDES, E.T.; FAVERO, S. Óleo essencial de Schinus molle L. para o controle de Sitophilus zeamais Most.1855 (Coleoptera:Curculionidae) em milho. Revista Brasileira de Agroecologia, v. 9, n. 1, p. 225-231, 2014.

ISMAN, M.B. Plant essential oils for pest and disease management. Crop Protection, v. 19, p. 603-608, 2000.

LIMA, R.K. et al. Caracterização química do óleo essencial de folhas de goiabeira (Psidium guajava L.) e seus efeitos no comportamento da lagarta-do-cartucho do milho Spodoptera frugiperda (J. E. Smith, 1797) (Lepidoptera: Noctuidae). Ciência e Agrotecnologia, v. 33, p. 17771781, 2009.

LORINI, I. Manejo Integrado de Pragas de Grãos de Cereais Armazenados. Passo Fundo: Embrapa Trigo, 2008. 72p.

MOSSI, A.J. et al. Insecticidal and repellency activity of essential oil of Eucalyptus sp. against Sitophilus zeamais Motschulsky (Coleoptera, Curculionidae). Journal of the Science of Food and Agriculture, v. 91, p. 273277, 2011.

MOSSI, A.J. et al. Essential oil of Ocotea odorifera: An alternative against Sitophilus zeamais. Renewable Agriculture and Food Systems, v. 29, p. 161-166, 2014. NEGAHBAN, M.; MOHARRAMIPOUR, S. Fumigant toxicity of Eucalyptus intertexta, Eucalyptus sargentii and Eucalyptus camaldulensis against stored-product beetles. Journal of Applied Entomology, v. 131, p. 256-261, 2007.

OOTANI, M.A. et al. Toxicidade de óleos essenciais de eucalipto e citronela sobre Sitophilus zeamais Motschulsky (Coleoptera: Curculionidae). Bioscience Journal, v. 27, n. 4, p. 609-618, 2011.

PIETRO, J.A. et al. Constituyentes químicos, actividad insecticida y antifúngica de los aceites esenciales de hojas de dos especies colombianas del género Ocotea (Lauraceae). Revista Colombiana de Química, v. 39, n. 2, p. 199-209, 2010.

PINTO JUNIOR, A.R. et al. Bioatividade de óleos essenciais de sassafrás e eucalipto em cascudinho. Ciência Rural, v. 40, n. 3, p. 637-643, 2010.

PIMENTEL, M.A.G. et al. Phosphine resistance in Brazilian populations of Sitophilus zeamais Motschulsky (Coleoptera: Curculionidae). Journal of Stored Products Research, v.45, p.71-74, 2009.

PROCÓPIO, S.O. DE et al. Bioatividade de diversos pós de origem vegetal em relação Sitophilus zeamais MOST. (Coleoptera: Curculionidae). Ciência e Agrotecnologia, v. 6, p. $1231-1236,2003$.

REICHERT J.R. et al. Estudo do efeito repelente, inseticida do óleo essencial de Baccharis dracunculifolia DC no controle de insetos (Sitophilus zeamais) em grãos de milho armazenados. Cadernos de Agroecologia, v. 8, n. 2, p. 1-5, 2013.

SOUZA, V.C.; LORENZI, H. Botânica sistemática: guia ilustrado para a identificação das famílias de Fanerógamas nativas e exóticas no Brasil, baseado em APG III. $2^{\text {a }}$ ed., Nova odessa, São Paulo: Instituto Plantarum, 2012.

TAPONDJOU, A.L. et al. Bioactivities of cymol and essential oils of Cupressus sempervirens and Eucalyptus saligna against Sitophilus zeamais Moutschulsky and Tribolium confusum du Val. Journal of Stored Products Research, v. 41, p. 91-102, 2005.

TAVARES, M.A.C.; VENDRAMIM, J.D. Bioatividade da Erva-de-Santa-Maria, Chenopodium ambrosioides L., sobre Sitophilus zeamais Mots. (Coleoptera: Curculionidae). Neotropical Entomology, v. 34, n. 2, p. 319-323, 2005.

TIBOLA, C.S.; LORINI, I.; MIRANDA, M.Z. de. Boas práticas e sistema APPCC na pós-colheita de trigo. Passo Fundo: Embrapa Trigo, 2009. 20p.

TORRES, E.; WISNIEWSKI JR, A.; SIMIONATTO, E.L. Composição química dos componentes voláteis de Capsicodendron dinisii SCHWANCKE (Canellaceae). Química Nova, v. 34, n. 1, p. 130-132, 2010.

TRIPATHI, A.K. et al. A review on prospects of essential oils as biopesticide in insect-pest management. Journal of Pharmacognosy and Phytotherapy, v. 1, n. 5, p. 52-63, 2009.

Rev. Bras. PI. Med., Campinas, v.17, n.4, supl. III, p.1055-1060, 2015. 